\title{
The education revolution on horseback I : The relation between Napoleon Bonaparte and education system characteristics
}

Citation for published version (APA):

Korthals, R. A. (2016). The education revolution on horseback I : The relation between Napoleon

Bonaparte and education system characteristics. Maastricht University, Graduate School of Business and Economics. GSBE Research Memoranda No. 014 https://doi.org/10.26481/umagsb.2016014

Document status and date:

Published: 01/01/2016

DOI:

10.26481/umagsb.2016014

Document Version:

Publisher's PDF, also known as Version of record

Please check the document version of this publication:

- A submitted manuscript is the version of the article upon submission and before peer-review. There can be important differences between the submitted version and the official published version of record.

People interested in the research are advised to contact the author for the final version of the publication, or visit the DOI to the publisher's website.

- The final author version and the galley proof are versions of the publication after peer review.

- The final published version features the final layout of the paper including the volume, issue and page numbers.

Link to publication

\footnotetext{
General rights rights.

- You may freely distribute the URL identifying the publication in the public portal. please follow below link for the End User Agreement:

www.umlib.nl/taverne-license

Take down policy

If you believe that this document breaches copyright please contact us at:

repository@maastrichtuniversity.nl

providing details and we will investigate your claim.
}

Copyright and moral rights for the publications made accessible in the public portal are retained by the authors and/or other copyright owners and it is a condition of accessing publications that users recognise and abide by the legal requirements associated with these

- Users may download and print one copy of any publication from the public portal for the purpose of private study or research.

- You may not further distribute the material or use it for any profit-making activity or commercial gain

If the publication is distributed under the terms of Article $25 \mathrm{fa}$ of the Dutch Copyright Act, indicated by the "Taverne" license above, 
Roxanne Korthals

The Education Revolution on Horseback I: The Relation between Napoleon Bonaparte and Education System Characteristics

$\mathrm{RM} / 16 / 014$

\section{GSBE}

Maastricht University School of Business and Economics

Graduate School of Business and Economics

P.O Box 616

NL- 6200 MD Maastricht

The Netherlands 


\title{
The Education Revolution on Horseback I:
}

\section{The Relation between Napoleon Bonaparte and Education System Characteristics ${ }^{1}$}

\author{
Roxanne Korthals
}

\begin{abstract}
Much research has been done into the emergence of mass education systems, primarily by studying the social origin of the education system, the introduction of compulsory schooling laws, or the expansion of enrolment rates. However, little is known about the origin of the characteristics of these newly formed systems. Ramirez and Boli (1987) argue that the threat for war with and invasion by the French around the 1800s induced European countries to introduce mass public education systems. This paper empirically establishes whether political pressure from Napoleon is related to the levels of differentiation and standardization of European education systems. I find that the political pressure from France is related to differentiation, but less to standardization of the content of instruction, and not at all to the existence of central exam and administrative standardization.
\end{abstract}

JEL codes: $\mathrm{I} 2$

Keywords: History of education, mass public education systems, tracking, standardization

\footnotetext{
${ }^{1}$ I would like to thank Jaap Dronkers and Sjoerd Karsten for bringing the paper of Ramirez and Boli (1987) under my attention, and the Forschungsdatenzentrum am Institut zur Qualitätsentwicklung im Bildungswesen and the IPN Kiel for providing me with the extended PISA data for Germany. I further would like to thank Francisco Ramirez, Barbara Belfi, Carla Haelermans, David Smith, and three anonymous referees for useful comments that have improved the paper. This paper is the first of two companion papers on Napoleon and differentiation in secondary education. The second is Korthals (2016).
} 


\section{Introduction}

For many people in the western world it would be difficult to imagine society without a universal and compulsory primary and secondary education system. However, mass public education is a relatively recent institution: the first mass public education systems emerged only in the nineteenth century. While in 2012 the enrolment rate at age 6 was on average $98 \%$ for OECD countries, with a minimum of $91 \%$ in Chile and the Slovak Republic (OECD, 2014), in 1870 primary education enrolment varied in Europe between 13\% in Portugal and 75\% in France (Soysal and Strang, 1989).

Research into the emergence of mass public education often entails case studies arguing for each country why the specific situation of that country led to the introduction of the nation specific education system (e.g. Archer, 1979; Go and Lindert, 2007). These case studies are often followed by theoretical reflections on common trends or sources of variation of the emergence of mass public education. Other work looks at cross country variation to find patterns of how mass public education spread (e.g. Soysal and Strang, 1989; Meyer et al., 1992). However, both strands of the literature focus on the emergence of mass public education systems itself. The aim of this paper is to look at the characteristics of these emerged mass public education systems.

In the education systems in Europe geographical clusters of countries can be distinguished. For instance, related to tracking, Scandinavian counties and the UK have very similar comprehensive education systems with only one track available to students and late selection. Contrary to that, Germany, the Netherlands, Belgium, Switzerland, and Austria have highly tracked systems with a high number of tracks and, in Germany and Austria, selection as early as 10 years old. These geographical clusters found in European education systems can be explained by Ramirez and Boli (1987) who propose that the threat of war with and annexation by the French in the 1800 s caused countries to set up mass public education systems.

The late 18th century in Europe was quite volatile with the Enlightenment, best seen by the French Revolution of 1789 and the Napoleonic Wars. The era of Napoleon Bonaparte started in 1800 when he made himself First Council of France. The following two decades the Wars dominated European politics and daily life, until 1815 when Napoleon was defeated at Battle of Waterloo. As laid out by Ramirez and Boli (1987), these external challenges induced European countries to create a national identity. An important part of this nation building, 
which would lead to a national identity, was the introduction of mass public educational systems by the national state. This was mainly intended to educate the future generations in the cultural and political traditions of the nation. Creating a national identity in war times is important for states since it increases the public's (physical and mental) willingness to pay (through taxes) and fight for the survival of their own nation in order to remain independent.

The aim of this paper is to investigate whether the proposed mechanism by Ramirez and Boli (1987) is related to the level of differentiation, i.e. tracking, and standardization in European education systems. I use data on education system characteristics for 29 European countries. The analyses show that there is a relation between the political pressure from France in the 1800 s and some, although not all, aspects of current day European educational systems. The political pressure from France in the 1800s, as theorized of Ramirez and Boli (1987), is related to tracking, both seen by the number of tracks available to fifteen-year-old students and by the age of first selection. There is only a small relation between the influence of Napoleon and standardization of the content of instruction, and no relation with the existence of central exams or administrative standardization, which concerns standardization for teacher hiring, salary increases, and formulating school budgets.

This paper is structured as follows: The next section provides a theoretical background on the emergence of mass public education systems and provides some insights into possible mechanisms for the origin of education system characteristics. This is followed by a discussion of the theory of Ramirez and Boli (1987) and an introduction to the history of French influence in the 1800s. Section 5 describes the data, while Section 6 presents evidence for the relation between political pressure from Napoleon and characteristics of education system. Finally, Section 7 provides a conclusion and a discussion.

\section{Theoretical background}

The literature on the emergence of mass public educations systems consists mainly of case studies on single countries or multiple countries, focused most often on France, Germany, England and the United States. The case studies of multiple countries are often followed by theoretical reflections on common trends or sources of variation. Some authors looked empirically at common trends in cross country variation. To my knowledge no researchers focused on formation of the characteristics of mass public education systems. However, in previous literature sometimes mechanisms explaining characteristics of mass public education 
systems are indirectly discussed. A few examples of this are given below. The theory of Ramirez and Boli (1987), which this paper uses extensively, is discussed in Section 3.

I focus here on the early emergence of mass public education systems. However, there is also extensive literature on the later expansion of education systems (e.g. Meyer et al., 1977; Goldin and Katz, 1997; 1998).

\subsection{Cross country analyses}

The most often mentioned causes for the emergence of mass public education systems, coming for theoretical and empirical works, are state interest in educated civilians and interaction among social groups in society and previous suppliers of education. Archer (1979) and Boli and Ramirez (1986) provide two major examples covering, respectively conflict theory and world society theory, which dominate the theories into the emergence of mass public education systems. There are also more descriptive histories without providing a comprehensive theory (e.g. Mueller et al., 1987; Cummings, 2010).

A very comprehensive analysis of the emergence of mass public education using multiple case studies is Margaret Archer's book Social origins of educational systems (1979). In this book Archer explains the rise of mass education systems based on the interactions of social groups within society. For this she uses the origins of the education systems in England, France, Russia, and Denmark as examples for her theory. Before the late 18th or 19th century, control of existing education systems was held by the dominant social group in society (often churches in various forms) and it supplied the graduates this dominant social group desired. Endogenous change of education systems could not be initiated because the education sector was dependent on the dominant group for all its inputs, like schools, teachers, and books. A theory of educational change, Archer argues, will thus have to be able to explain educational change from outside the education sector where the dominant social group was challenged by opposing social groups. These "assertive groups" were not (fully) able to benefit from the education system (and its outputs) and therefore these groups, when it became profitable, tried to diminish or even destroy the power the dominant group had on the educational system and setup a mass public education system.

Boli and Ramirez (1986) argue that education systems must be seen as institutions in a transnational world, and thus that the emergence of education systems was not due to local 
national events alone but that these systems emerged as part of the world culture. ${ }^{2}$ The emergence of mass public education systems was possible due to (1) the increased importance of the individual in everyday thinking, (2) the move from seeing children as miniature adults to creatures of innocence needing education, (3) the emergence of the state and nationalism, (4) changes in religion and religious practices, (5) the emergence of the nation-state in a transnational world, and (6) economic expansion. The emergence of the nation-state was vital since it was mainly the increased (economic and strategic) competition between countries that induced countries to introduce mass public education systems.

Soysal and Strang (1989) provide an empirical cross country investigation into the emergence of mass public education systems. They look at the timing of compulsory schooling laws and the growth in primary school enrolment in 17 western countries and focus primarily on the role of the relation between state and church in this. Soysal and Strang (1989) find that in countries which had a national church, compulsory schooling laws were introduced earlier, possibly because having a national church meant there was little conflict with the previous provider of schooling, since these were most often churches. But for countries without a national church, the earlier a country had compulsory schooling laws the less growth in enrolment it had, possibly because those states lacked organizational strength to set up public education systems.

Meyer et al. (1992) consider common factors for one aspect of the formation of mass public education: the expansion of enrollment in education. They find that the timing of entry into mass public education mattered and that this depended on the integration of the country in the world society. But once countries formed mass public education systems, all followed the same pattern in their enrollment expansion. Thus a common pattern was found for a wide variety of countries.

\subsection{Single country case studies}

In studies where only a single country or education system is studied the reasons for the emergence of education and its early expansion are very diverse. Since country specific circumstances are not the focus of this paper, the following recent studies, which are by no means exhaustive, are merely for illustrative purposes.

\footnotetext{
${ }^{2}$ Another example of how the state became interested in mass public education for nation building is Green (1990).
} 
Becker and Woessman (2006) look at an outcome measure of mass education, the spread of literacy in Prussia. Becker and Woessman (2006) find a positive effect of the spread of Protestantism, in which followers are encouraged to read the Bible themselves, on literacy rates, pointing towards a religion induced emergence of education. Westberg (2015) ties the emergence of mass public education in Sweden to the construction of school buildings, which were required to facilitate the emergence of the mass public education system. For the United States, scholars emphasize the decentralized nature of the emergence of the education system and focus more on local circumstance which influenced the costs of education and voting power as reasons for expansion (Beadie, 2010; Go and Lindert 2007).

\subsection{Characteristics of mass public education systems}

An example of how the origins of the characteristics of education systems were indirectly discussed is Archer (1979). As described above, Archer's book explains the rise of mass education systems in terms of interactions of social groups within society. She continues by posing that change in education systems arose using one of two strategies. One strategy, the substitutive strategy, was that existing schools and curricula, controlled by the initially dominant group, were supplemented by schools and curricula from an assertive group. The other strategy, the restrictive strategy, was that the existing education system was forced to obey the regulations of an assertive group, which obtained, and was able to execute, state control, and was transformed accordingly. Following these, whether the substitutive or restrictive strategy was used points towards an explanation for the level of standardization and the extent of tracking in the education system in a country. In the countries where substitutive strategies were used, multiple school systems existed alongside each other as separate "tracks" and standardization was low. But in countries where restrictive strategies where used, the existing school system was transformed in one single "new" school system using state regulations. Following this, differentiation was low and standardization was high.

Another example of a study which indirectly discusses possible mechanisms for the origins of education system characteristics is Boli et al. (1985). Boli et al. (1985) describe two development paths of education systems which were used to transform individuals into members of society: the model of "creating societal members" and the model of "creating members of the nation-state". The model of creating societal members would lead to a "top down model": a decentralized education system with little regional variation since the societal model was identical across regions. Such a structure could have led to low levels of 
standardization and high levels of autonomy, but also to low levels of differentiation since all followed the same societal model. The model of creating members of the nation state would lead to a uniform education system so that all citizens would adhere to the same set of principles and ideas and it would be more rule based. Countries which followed this model would display stronger standardization and low autonomy.

Soysal and Strang (1989) argue that a unified education system was more likely when private and religious parties worked together and did not oppose each other. Churches often opposed the attempts of the state to introduce mass public education, especially when they themselves fulfilled that role at that point in time. But when the church and state were very intertwined, for instance when the country had a national church, a unified education system could still emerge even though the church was previously the principal supplier. Similarly to the implications from Archer (1979) this could imply more standardization and less differentiation in such systems.

\section{Ramirez and Boli (1987): The Political Construction of Mass Schooling}

This section provides a discussion of the theory proposed by Ramirez and Boli (1987). This theory relates external challenges of the country to the introduction of mass public education systems. The different stages of this process are discussed, and examples are given.

\subsection{A theory on the origins of education systems ${ }^{3}$}

In their 1987 paper The Political Construction of Mass Schooling: European Origins and Worldwide Institutionalization Ramirez and Boli present their theory on how external pressure led to similar events in multiple countries which eventually led to the introduction of mass public education systems in the nineteenth century. Or as said by Ramirez and Boli (1987): "Our view is that European states became engaged in authorizing, funding, and managing mass schooling as a part of the endeavor to construct a unified national policy. [...] External challenges [...] were important stimuli to state action in education [...]" (p. 3). Of the external challenges on the European continent in this era the Napoleon Wars were perhaps the most extreme. The external challenges were not purely military pressure; it was a broader political pressure: it was a reaction to the French, but not imposed by the French army. These challenges caused countries to set up mass public education systems.

\footnotetext{
${ }^{3}$ This section is based upon Ramirez and Boli (1987).
} 
The theory of Ramirez and Boli (1987) is formed by using case studies of seven European regions: Prussia, Denmark, Austria, Sweden, Italy, France, and England. Prussia and Denmark were early in setting up mass public education systems. Sweden, France, and England follow later. Italy is an intermediate case since the South was relatively late (like France and England), while the North was relatively early (like Prussia and Denmark). This supports the claim by Ramirez and Boli (1987) that regions that faced external challenges introduced mass public education systems while "the most dominant powers were able to resist the system wide pressures favoring mass education [...]." (Ramirez and Boli, 1987, p. 4).

Although national events and characteristics naturally played a large role in the origins of education systems, Ramirez and Boli (1987) focus only on "transnational similarities in the institutional character of state educational systems" (p. 2). Each of the regions discussed by Ramirez and Boli showed the same pattern in response to external challenges. These patterns follow four steps (p. 9). First there was a "declaration of a national interest in mass education". In Germany this can be seen by an address by the German philosopher Johann Gottlieb Fichte in 1807 which stated that "universal state-directed, compulsory education would teach all Germans to be good Germans and would prepare them to play whatever role [...] fell to them in helping the state reassert Prussian power" (p. 5). In Denmark this can be seen by the claims between 1807 and 1814 by N.F.S. Grundvig, a clergyman, that education “[is] a means for Denmark to regain its spiritual and national strength" (p. 6). Also in Italy: "Education was seen as a means of increasing Italian power and prestige" (p. 7).

The second step on the route towards mass public education was "legislation to make schooling compulsory". Although most states had some legislation of education in place in the $18^{\text {th }}$ century, often it was neither mandatory, nor universal, nor free. Secondly, in some cases legislation was set up but the necessary funds were not delivered and thus the legislation was not put into practice, as was for instance the case in Prussia in 1717 and in Denmark in 1739. Prussia was one of the first regions which provided state mass education and also established a tax instrument to finance it, but only after 1817.

With the legislation in place, the "creation of a state educational ministry or department" and the "establishment of state authority over existing and new schools" were possible. Prussia established a Bureau of Education in 1806 and after 1817 the state provided certification of 
teachers, while in England only in 1944 a national ministry of education was formed to act as the central education authority. Churches often had influence on education until well in the 19th century. In Austria in 1855 full control of education was given back from the state to the church and even in Prussia, the government announced in 1844 that "religious instruction is more important than pedagogical theory".

\subsection{Education system characteristics and possible mechanisms}

Although previous literature has stated theories on the emergence of education systems, it has not done so for the emergence of education system characteristics. Also the theory of Ramirez and Boli (1987) only states that countries that faced external challenges set up mass public education systems earlier than other countries. It does not speak about the characteristics of these education systems. In Section 2.3 a possible explanation for the levels of differentiation and standardization following Archer (1987) was already given: When the state introduced the mass public education system, it could take over existing schools (restrictive strategy), or newly formed mass public education schools could existed side by side with already existing schools, with perhaps different curricula and structures (substitutive strategy). States that introduced an overall education system early on (for instance those states that were under external pressure) had probably weaker state systems than those who introduced an overall education system later, simple because states got more developed and centralized over time. When the education system was introduced earlier, perhaps more often the state system existed next to the existing system, or in other words substitutive strategies were used. These substitutive strategies might have led to different school types within one system, or in other words different tracks. And it might also be that these different school types had different pedagogical views, textbooks, and courses and therefore standardization might be low. Countries that formed education system later could force the existing schools into a unified system with low levels of differentiation and high levels of standardization.

The above example of how the timing of the emergence of mass public education influenced the characteristics of the mass public education systems is only for illustrative purposes. In the rest of this paper I link the theory of Ramirez and Boli (1987) on the origin of education systems to characteristics of education systems. I do not extensively discuss the mechanisms at play, but I acknowledge that more insights into the mechanisms are necessary. 


\section{The Napoleonic wars ${ }^{4}$}

The external challenges, referred to by Ramirez and Boli (1987) were in most cases (political) pressure arising from the French army and later, and foremost, from Napoleon Bonaparte. The current section gives a short summary of the Napoleonic wars and its impact on the European continent.

After the turmoil of the French Revolution and its aftermath, Napoleon Bonaparte, a general who just secured victories for France in Italy, Austria, and Egypt ${ }^{5}$, was called in to support a coup d'état by the National Convention, consisting of the bourgeois who wanted to overthrow the everlasting power of the clergy and the nobility. However, Napoleon took power for himself in November 1799 and declared himself First Consul in 1800.

Almost as soon as Napoleon took power, he invaded neighboring countries, annexed Piedmont in Italy, the Rhineland in Germany and Belgium, and appointed himself president of the Republic of Italy and Mediator of the Swiss Confederation. In 1802 the peace treaty of Amiens was signed by France, England, Holland (part of the current day Netherlands) and Spain. But the peace did not last long as Napoleon kept intervening in neighboring countries and setting up strategic positions against England, the most dominant (naval) power at the time. Soon after his coronation as Emperor of France in 1804, Napoleon annexed the Ligurian Republic (1805, Italy, south of Piedmont). In response, in 1805 the Russian Empire and England formed an alliance against France, which Austria (the Habsburger Empire), Sweden, and Naples later also joined. Napoleon formed alliances with Spain and Bavaria in return. Despite the alliance with Russia and England, Austria was conquered and was given harsh settlement terms and had to give up a number of territories. France was also able to force Prussia into submission: Prussia had to end trade with England but received the conquered region of Hanover from France in return. Napoleon conquered Berlin and later also invaded Prussia's Poland and established the Duchy of Warsaw. On his way east, Napoleon successfully fought Prussia and Russia in 1807. Following that defeat, Russia had to acknowledge Napoleon's brothers as rulers of Naples, Holland, and Westphalia and in return Napoleon would leave the Baltics states and Turkey alone. Prussia had to give up territories to

\footnotetext{
${ }^{4}$ This paragraph is based on Santon and MacKay (2010) and Chapter 1 and 13 of Grab (2003).

${ }^{5}$ Napoleons journey to Egypt did not end as well as it started. After Napoleon conquered Egypt, and with it was able to frustrate the trade routes of England, he lost most of its fleet in the Battle of Aboukir and was unable to return home. Napoleon ruled Egypt for over about a year before leaving behind his army and returning to France in 1799.
} 
the Kingdom of Westphalia and the Duchy of Warsaw, which were under Napoleons influence, pay damages, and accept limitations on its army.

In 1808, while the French army was mostly tied up in Spain, Austria started to make preparations to go to war against France. The war was fought in Germany, Austria Italy, and Poland and in 1809 Austria conceded. France received the Illyrian Provinces ("Croatia"), while also Bavaria and the Duchy of Warsaw received lands from Austria. Furthermore, Austria had to pay damages and obey limitations on its army. Later Napoleon married the daughter of Francis I, the emperor of Austria, and thus formed an alliance between both houses. Pope Pius VII opposed the marriage, as he had not approved Napoleon's divorce from his former wife Josephine, and also refused to prevent England ships from using its ports. In response Napoleon marched south to Rome. In 1809 Napoleon had taken over control of Rome and the remaining Papal States and exiled Pope Pius.

Napoleon became less popular in France over the year with the continued fighting, the exile of Pope Pius VII in 1809, and continued trade blockades. Napoleon advanced into Russia since they did not uphold the agreed trade blockage towards England, but was unsuccessful. Following that defeat Russia, Prussia, England, Sweden, and Austria united against France. Napoleon also faced problems at other fronts and he abdicated when Paris was taken in April 1814. After the Battle of Waterloo, Napoleon was defeated and he was exiled to St. Helena where he died in 1821.

Under Napoleons reign the French Empire grew substantially: At the height of the French Empire in 1810 it covered an area of 750,000 square kilometers (293,000 square miles) as compared to 543,965 square kilometer (210,026 square miles) for Metropolitan France today. There were "allied countries whose territory was expanded by Napoleon in some cases, and continued to be governed by their native rulers", like Bavaria and Sweden. Grab (2003) calls these the pays allies. The conquered or annex countries were either "countries annexed to France and directly ruled by Napoleon" (pays réunis), like Belgium and Piedmont, or "satellite states that were entrusted to French rulers" (pays conquis), like Spain and Switzerland (Grab, 2003). But not all territories were under French control. Figure 1 shows the categorization of Europe by Grab. 


\section{Data and method}

The data used in this paper covers 29 countries in the sphere of influence of 1800s France. I use data on the level of differentiation in education systems, the level of standardization in education systems, and the political pressure from Napoleon from various sources.

\subsection{Sample of countries}

In this paper only countries in the direct sphere of influence of Napoleon are included, which limits the countries to European countries. France itself is excluded since the proposed theory of political pressure from the French does not work on France itself. The included European countries are Austria, Belgium, Switzerland, Czech Republic, Germany, Denmark, Spain, Finland, United Kingdom, Croatia, Hungary, Italy, Luxembourg, Netherlands, Norway, Poland, Portugal, Slovak Republic, Slovenia, and Sweden.

In a few instances it was possible to divide countries into regions more suitable for either the historical categorization of the French threat (Germany and Italy) or for the display of education systems (Germany, Belgium and Great Britain). Germany and Italy were not yet united countries in the 1800s. In Germany a large number of states, city states and kingdoms existed and the borders and the independence of these regions changed numerous times. Germany is therefore split into 6 regions: Bavaria, Hanover, Prussia, Rhineland, Saxony, Westphalia. ${ }^{6}$ Italy was similar to Germany in the 1800 s in the sense that it consisted of a number of states and kingdoms and was only later united in a single country. For the analyses here Italy was split into 3 regions: the North West, the Republic of Italy, and the Kingdom of Naples. ${ }^{7}$ Both Belgium and Great Britain are divided in two regions that better represent the education systems (and also the cultural regions). Belgium is divided in the Flemish region

\footnotetext{
${ }^{6}$ To be able to match the current German states to the regions in the 1800 s a division of Germany is made. In this paper Westphalia refers to the current German states Hesse and North Rhine-Westphalia. The Rhineland is the German states Saarland and Rhineland-Palatinate. Prussia consists of Mecklenburg-Vorpommern, Berlin, Brandenburg, and Saxony-Anhalt. Bavaria is Bavaria and Baden-Wurttemberg. Hanover consists of the German states Hamburg, Bremen, and Lower Saxony, while Saxony refers to Saxony and Thuringia. Schleswig-Holstein belonged to Denmark around 1800 and is therefore display as a single territory in the historical maps and is excluded from the maps depicting standardization. The standardization maps are made using PISA2006 data and it would be very difficult and arbitrary to add the Danish and Schleswig-Holstein data to create one "Greater Denmark". The division of German states into the regions described above, instead of using all German states separately, is used since it is not allowed to display results for individual German states using the PISA 2006 data. It is allowed however to use clusters of states, which led to the creation of the region described here.

${ }^{7}$ This paper distinguishes four regions in Italy in the 1800s: The North West consisting of current day Liguria, Piemont, and Sardinia, The Republic of Italy consisting of Bolzano, Trento, Emilia-Romagna, Friuli-Venezia Giulia, Lombardy, and Veneto, The Kingdom of Naples: Basilicata, Campania, Puglia, Provincia Sicilia. The other Italian provinces are Abruzzo, Lazio, Marche, Molise, Tuscany, Umbria, Valle d'Aosta, and Calabria. Of these eight provinces the first six can be regarded as the Papal State while Valle d'Aosta could be assigned to the North West and Calabria was part of the Kingdom of Naples. However, in PISA2006 it not possible to distinguish between these eight provinces and therefore these provinces are excluded from the maps and analysis using standardization.
} 
and the French region (including the German speaking parts), while Great Britain is divided in Scotland and the region consisting of England, Wales, and Northern-Ireland. These subdivisions lead to a total of 29 regions, which is referred to as countries from now on for simplicity.

\subsection{Data on education systems}

The focus here is on two main education system characteristics: the level of differentiation and the level of standardization in education systems.

Differentiation is measured both by the number of distinct education programs (tracks) available to students at age 15 and by the age of first selection. Data on the number of tracks are from the OECD (2007, Table 5.2) and adjusted for Flemish and French Belgium (using information on Eurydice) and for the Germany states (using Woessmann, 2007). Data on the age of first selection are from the OECD (2007, Table 5.2) and adjusted for Flemish and French Belgium (using information from Eurydice) and for the Germany states (using Kultusminister Konferenz, 2013). Descriptive statistics on differentiation are shown in Figure 2 and Table 1 . Table 1 shows that for the 29 countries the number of tracks varies between 1 (a comprehensive system) to 5. Some countries select students already at age 10, while others select only at age 16. Figure 2 shows that countries in the periphery of Europe have less differentiation (both measured by the age of first selection and by the number of tracks) than countries in the inner region.

---Figure 2 here---

---Table 1 here---

Standardization is split into standardization of outputs and standardization of inputs. Outputs are standardized when students are required to learn the same curriculum. A proxy for this is whether or not an education system has central exit examination (CEE). Data on CEEs examinations are from OECD (2011, Table D5.1a) and adjusted for the German states using Juerges et al. (2005). Unfortunately, for Switzerland, Croatia and Slovenia I have no information on the existence of CEEs. Table 1 shows that 42 percent of countries in the sample have CEEs, while Figure 2 shows the same data per country. 
Data on input standardization are from the Program for International Student Assessment (PISA) 2006, and relates to answers given by school principals on who has authority for the textbooks, course content, teacher appointments, teacher employment conditions, and budget. These last five variables are transformed into two country averages, one on the administrative aspects (consisting of information on teacher hiring, salary increases and formulating the budget) and standardization on content related issues (consisting of information on textbook choice and course content). Table 1 shows there is large variation in the amount of standardization across countries. Figure 2 shows the same data per country.

\subsection{Data on the political pressure from Napoleon}

The political threat from Napoleon is modelled in this paper in three ways. The first is by the distance of one's own capital to Paris. The air distance between Paris and the capital around 1800 in Table 1 is given in kilometres, where 500 kilometres are added for a sea crossing. Belgium's Brussels is closest to Paris with a distance of $264 \mathrm{~km}$, while Finland's capital of Turku is furthest away with $2304 \mathrm{~km}$.

In the 1800s there were more empires in Europe than just the French Empire. Belonging to an empire would have either protected the country from outside threat due to the larger protective force of an empire compared to a (smaller) country and thus lowered the threat from Napoleon, or it would have increased the threat when there were struggles between Napoleon and the empire in question. The countries belonging to empires in the nineteenth century are shown in Figure 3. Together with the distance to Paris, this is a proxy of the exante political threat of Napoleon, since it uses the threat for those at the time and does not display simple those countries that were actually involved in the fighting.

---Figure 3 here---

A measure of the ex-post threat used in this paper is the categorization by Grab (2003), as explained in Section 4 and shown in Figure 1 before. This is an ex-post measure since it relates to which countries were actually annexed and not which countries were under threat. The categorization from Grab (2003) divides the European countries into pays réunis, pays conquis, and pays allies. 
Table 2 provides pairwise correlations between the independent and dependent variables in the coming analyses. The two measures of differentiation are highly correlated (-0.59), while the standardization measures are much less correlated (in absolute values all between 0.01 and 0.33). The correlation between the distance to Paris and the categorization from Grab (2003) is also quite substantial. However, the correlation between the Grab dummies is rather low. Looking at the correlations, the distance to Paris seems to be predictive for less differentiation. The next section discusses this further.

---Table 2 here---

\subsection{Methodology}

The model estimated in this paper is depicted in equation (1). It relates education system characteristics, $E D U_{i}$, to proxies depicting the political pressure from Napoleon, $\operatorname{NAPOLEON}_{i}$, for country $i$. The education system characteristics are differentiation and standardization, as mentioned above. The political pressure from Napoleon is proxied by five different variables described above: the distance between one's own capital and Paris, whether the country belonged to an empire and a categorization of annexed and conquered countries.

$$
E D U_{i}=\beta_{0}+\beta_{1} N A P O L E O N_{i}+\varepsilon_{i}
$$

To investigate which proxies for the political pressure from Napoleon can best capture the variation in the data four models are estimated for each education system characteristic. The four models each use a different combination of the five available proxies.

\section{Results}

This section supplements the theory of Ramirez and Boli (1987) by empirical evidence that the political pressure from Napoleon is related to characteristics of European education systems.

Table 3 shows different models relating the distance to Paris, whether or not countries belonged to an empire, and the categorization by Grab (2003) to the number of tracks available in a country. The first model shows only the relation between distance and the number of tracks available and shows a strong negative correlation, meaning that the further away one's own capital is from Paris the fewer tracks its education systems will have. The 
size of the coefficients tells us that moving away 500 kilometers from Paris (about one standard deviation in the sample) leads to one less track. Whether this interpretation of the coefficient is very informative is unclear since the distance is just a proxy of the political pressure of Napoleon.

---Table 3 here---

Model 2 uses both the distance and the empire dummy, and is therefore the preferred model since it relates most closely to the ex-ante political threat by Napoleon. This model has a lot of power, explaining forty-five percent of the variation in differentiation. Countries belonging to an empire in 1800 have one more track available to students than countries not belonging to an empire in 1800. But again this precise interpretation of the coefficient is probably not fully informative. The coefficient for the distance to Paris is very similar to the previous model.

Model 3 uses the historical categorization of Grab combined with distance. Model 4 includes all independent variables and these are jointly significant.

The four models do remarkably well: They explain twenty-nine to forty-five percent of the variation and the variables in all models are jointly significant. The estimates say that countries that have their capital further away from Paris have fewer tracks available to pupils nowadays. Countries that were part of an empire have more tracks. Annexed countries ruled by Napoleon (pays réunis) have more tracks, while other annexed or allied countries have fewer tracks.

Table 4 shows the same models but now for the age of first selection. Also here the models are capable of explaining a significant part of the variation in the age of selection. Almost all the coefficients have the reversed signs as compared to Table 3. This is to be expected since the number of tracks available in a country and the age of first selection are highly negatively correlated (-0.59 in this sample). However all four models show considerably lower adjusted $\mathrm{R}$ squared than in Table 3.

---Table 4 here--- 
Table 5 shows the models using central examinations as dependent variable. What is immediately clear is that although the pressure of Napoleon has a relation to the two measures of differentiation; it has no such relation with central exit examinations. No model has jointly significant variables and the adjusted $\mathrm{R}$ squared is negligible. Perhaps the existence of central exit examination is too recent to be affected by the political pressure from Napoleon, or the use of central exit examinations changed too much over the years.

---Table 5 here---

Table 6 shows how that the pressure from Napoleon is also not related to the level of standardization on administrative issues. None of the coefficients is significant, also not jointly.

---Table 6 here---

The relation between the pressure from Napoleon and content related standardization is very small, but Model 3 of Table 7 does show jointly significant correlations. Annexed countries rules by Napoleon (pays réunis) seem to have more content related standardization.

---Table 7 here---

All in all, pressure from Napoleon does seem to have a relation with some aspects of education systems in Europe; most notably with differentiation, as seen by the number of tracks and age of selection, and content related standardization. For the number of tracks in a country, the proposed variables are able to explain twenty-nine to forty-five percent of the cross country variation. For the age of selection the pressure from Napoleon is able to explain around twenty percent. These results therefore provide support for the thesis of Ramirez and Boli (1987).

\section{Conclusion and discussion}

The existence of almost universal enrolment of children in public schools is relatively recent. Only in the nineteenth century did countries start forming mass public education systems. Although each country had its own specific circumstance during, and causes for, the emergence of these education system, research has found common factors and trends across 
countries. However, little is known about why countries shaped their education systems as they did, or in other words how the characteristics of the newly formed education system came about. Since the setup of most western education systems have changed only marginally since their initial introduction, the characteristics of most education systems we see today are mainly due to history and tradition and thus the initial characteristics of the education systems keep influencing students today. Furthermore, the characteristics of education systems, for instance the levels of differentiation and standardization, affect student performance today (e.g. Hanushek and Woessman, 2006) which affects later life outcomes. Therefore, it is relevant to know more about the origin of education system characteristics.

This paper builds on the 1987 paper of Ramirez and Boli The Political Construction of Mass Schooling: European Origins and Worldwide Institutionalization. In this paper, Ramirez and Boli argue that the introduction of European education systems in the nineteenth century was induced by external challenges on the continent. One of the most pronounced challenges was the political pressure from Napoleon, who dominated the continent for two decades. Almost all European countries were at one stage involved with Napoleon and many wars were fought on numerous battlefields. To unite the people and ensure a strong and willing workforce, countries introduced mass public education systems to educate the people as citizens of the nation willing to fight for independence. In this manner, political pressure from Napoleon had an influence on European education systems.

The current paper empirically tests whether the proposed mechanism of Ramirez and Boli (1987) also is related to the level of differentiation and standardization in European education systems. Especially for differentiation, both seen by the number of tracks and age of selection, a relation between education systems and the political pressure from Napoleon in the nineteenth century is found. The preferred models which capture the ex-ante political pressure from Napoleon are able to explain thirty-two to forty-five of the cross country variation in the number of tracks available to students and little below twenty percent for the age of selection. For standardization relating to the instructional content, school administration or the existence of central exit exams, no or a much weaker relation is found. Still, the theory proposed by Ramirez and Boli (1987) is supported by empirical evidence on specific education system characteristics. Although previous studies have sometimes indirectly addressed possible mechanisms for the formation of the characteristics of mass public education systems, none 
have focused on this. This paper makes a first attempt at analyzing historical education system characteristics, but does little to explain the mechanisms which played a role.

In the early literature of the effect of education on aggregate outcomes, such as gross domestic product (GDP) or average student performance, the focus was on years of education or enrolment rates, or said differently on the "quantity of education" (e.g. Barro, 1991). Later the focus shifted to the "quality of education" captured by test score averages or education system characteristics. These measures were better able to capture the actual difference in human capital across countries (e.g. Hanushek and Kimko, 2000; Hanushek and Woessman, 2006; Hanushek and Woessman, 2009). The focus of studies on the emergence of mass public education systems is still mainly on the "quantity of education", for instance by looking at enrolment rates. I argue that also here a shift to the qualitative aspects of the emergence of mass public education systems is in order. This analogue with analyses on the effect of education on aggregate outcomes provides a possible new direction for the field of the emergence of mass public education. 


\section{References}

Archer, M. (1979) Social Origins of Educational Systems. SAGE Publications Ltd: London.

Barro, R. (1991) Economic Growth in a Cross Section of Countries. Quarterly Journal of Economics, 106, pp. 407-43.

Becker, S. and L. Woessman (2009) Was Weber wrong? A Human Capital Theory of Protestant Economic History. The Quarterly Journal of Economics, May, pp. 531-596.

Boli, J. and F. Ramirez (1986) World Culture and the Institutional Development of Mass Education. In: J. Richardson (eds.) Handbook of theory and research for the sociology of education. Greenwood Press: US.

Boli, J., F. Ramirez, and J. Meyer (1985) Explaining the Origins and Expansion of Mass Education. Comparative Education Review, 29(2), pp. 145-170.

Centennia Software (2002) Centennia Historical Atlas: French Revolutionary and Napoleonic Era from 1789 to 1819. www.historicalatlas.com.

Cummings, W. (2010) How education systems form and reform. In J. Zajda and M. Geo-JaJa (eds.) The Politics of Education Reform. Globalization, Comparative Education and Policy Research nr 9. Springer.

GADM database of Global Administrative Areas (2013) Codes and software for making maps in Stata. www.gamd.org.

Grab, A. (2003) Napoleon and the Transformation of Europe. Palgrave MacMillan: England.

Go, S. and P. Lindert (2007) The Curious Dawn of American Public Schools. NBER Working Paper Serie, no. 13335.

Goldin, C. and L. Katz (1997) Why the United States Led in Education: Lessons from Secondary School Expansion, 1910 to 1940. NBER Working Paper Serie, no. 6144.

Goldin, C. and L. Katz (1998) Human Capital and Schooling: The Rise of Secondary Schooling in America, 1910 to 1940. NBER Working Paper Serie, no. 6439.

Green, A. (1990) Education and State Formation: The Rise of Education Systems in England, France and the USA. Macmillan.

Hanushek, E. and D. Kimko (2000) Schooling, Labor-Force Quality, and the Growth of Nations, American Economic Review, 90, pp. 1184-1208.

Hanushek, E. and L. Woessmann (2006) Does Educational Tracking Affect Performance and Inequality? Difference-in-Difference Evidence Across Countries. Economic Journal, 116, pp. C63-C76.

Hanushek, E. and L. Woessmann (2009) Do Beter Schools lead to more Growth? Cognitive Skills, Economic Outcomes, and Causation. NBER Working Paper Serie, no. 14633. 
Horloge Parlante (2013) http://www.horlogeparlante.com/nl/distance.php.

Juerges, H., K. Schneider, and F. Buechel (2005) The Effect of Central Exit Examinations on Student Achievement: Quasi-Experimental Evidence from TIMSS Germany. Journal of the European Economic Association, 3(5), pp. 1134-1155.

Korthals, R. (2016) The Education Revolution on Horseback II: Using the Napoleonic Wars to Elicit the Effect of Tracking on Student Performance. ROA Research Memorandum, no. $2016 / 6$.

Kultusminister Konferenz (2013) Übersicht über die Bildungsgänge und Schularten im Bereich der allgemeinen Bildung. Available at: http://www.kmk.org/fileadmin/pdf/Bildung/AllgBildung/SchemaBildungsgaenge_und _Schularten-Stand_2012-12.pdf (accessed 05-08-2013).

Meyer, J., F. Ramirez, and Y. Soysal (1992) World Expansion of Mass Education, 1870-1980. Sociology of Education, 65(2), pp. 128-149.

Mueller, D., F. Ringer, and B. Simon (1987) The rise of the modern educational system: structural change and social reproduction 1870-1920. Cambridge University Press.

OECD (2007) Science competenties for tomorrows world. OECD: Paris.

OECD (2011) Education at a Glance 2011: OECD Indicators. Table D5.1a. National examinations at the lower secondary level (2009). OECD: Paris.

OECD (2014) Education at a Glance 2014: OECD Indicators. Table C2.1. Enrolment rates in early childhood and primary education, by age (2005, 2012). OECD: Paris.

Ramirez, F. and J. Boli (1987) The Political Construction of Mass Schooling: European Origins and Worldwide Institutionalization. Sociology of Education, 60, pp. 2-17.

Santon, R. and L. MacKay (2010) Grote atlas van de wereldgeschiedenis. Paragon: UK.

Soysal, Y. and D. Strang (1989) Construction of the First Mass Education Systems in Nineteenth-Century Europe. Sociology of Education, 62(4), pp. 277-288.

Woessmann, L. (2007) Fundamental Determinants of School Efficiency and Equity: German States as a Microcosm for OECD Countries. IZA Discussion Paper Serie, nr. 2880

World Bank (2012) World Development Indicators \& Global Development Finance Database. Available at: http://databank.worldbank.org/data/home.aspx (Last accessed 23-03-2012.)

Westberg, J. (2015) Multiplying the origins of mass schooling: an analysis of the preconditions common to schooling and the school building process in Sweden, 18401900. History of Education, 44(4), pp. 415-436. 


\section{FIGURES}

Figure 1: The reach of the French Empire (based on Grab, 2003)

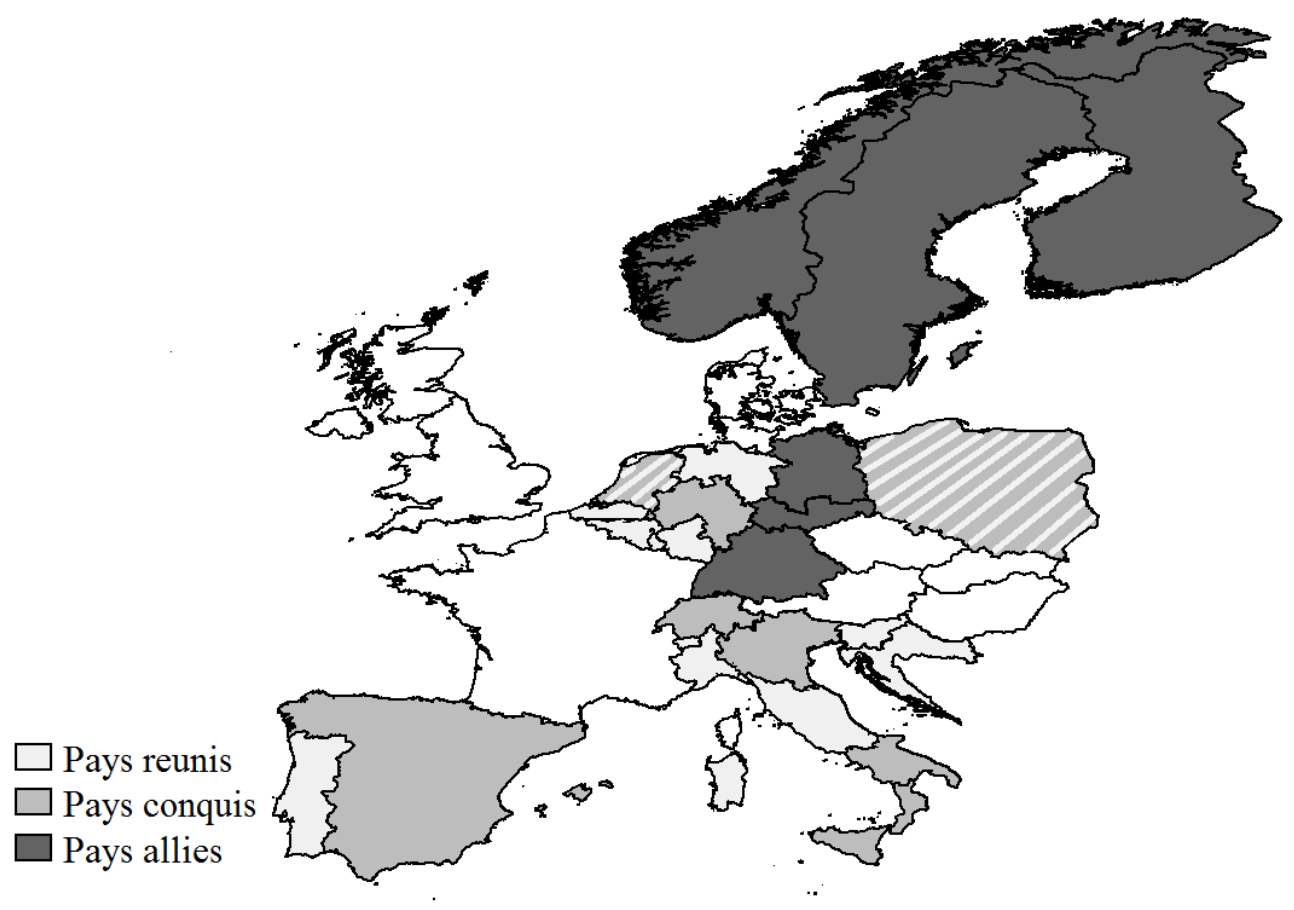

Note 1: The Netherlands and Poland were both pays réunis and pays conquis.

Note 2: The borders of the maps used in this paper are drawn by using the command spmap in Stata making use of the Shape files and the dBase databases of the European countries found on www.gamd.org. Thus the maps here are drawn using the current borders of the European countries. This means that country borders in the historical maps could (and most probably will) deviate from the historical borders in a number of ways. For simplicity it is chosen here to ignore these changes. 
Figure 2: Education systems in Europe

a. Number of tracks

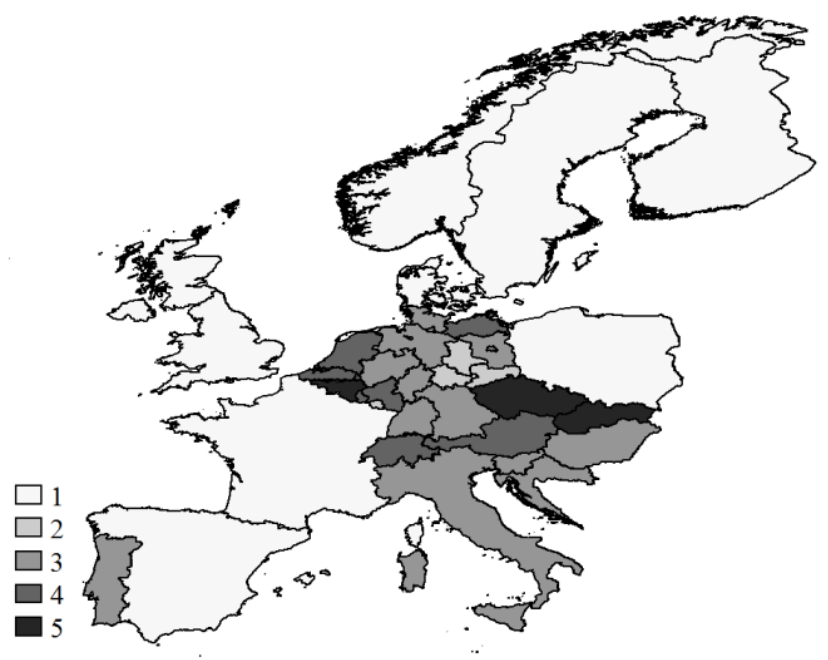

c. Central exit exams

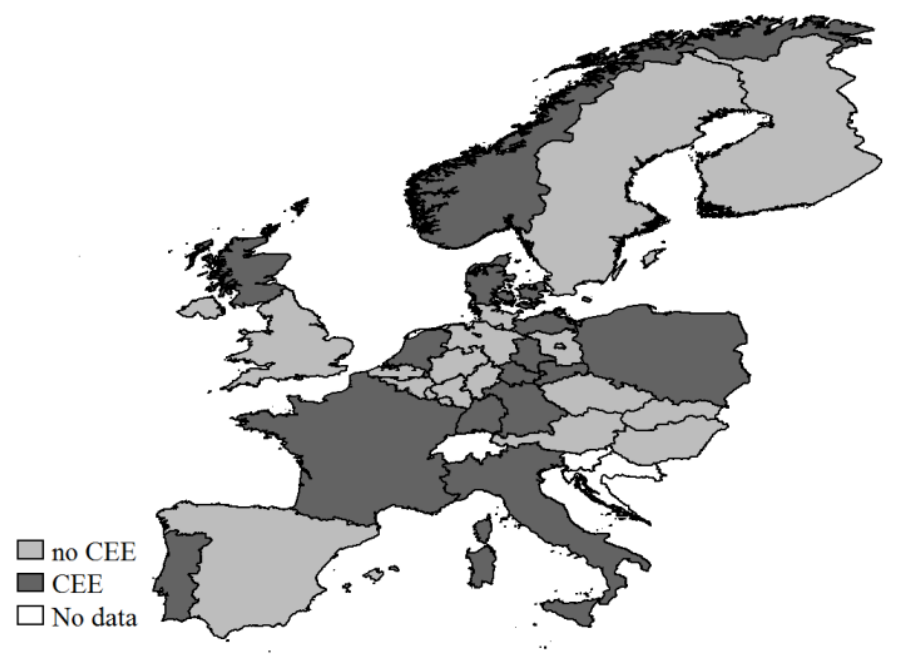

b. Age of first selection

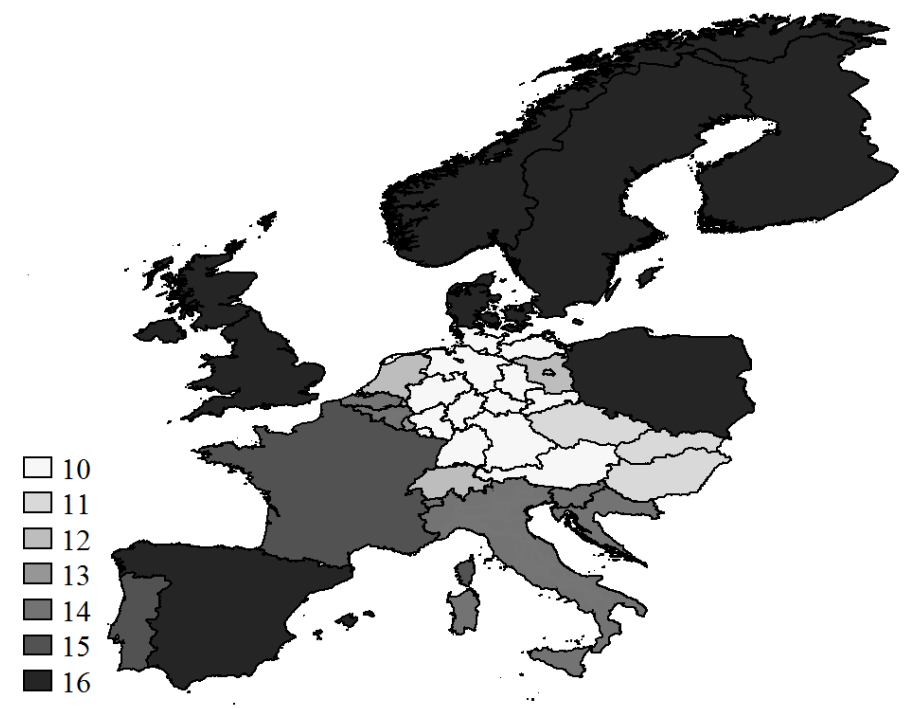

d. Administrative administration

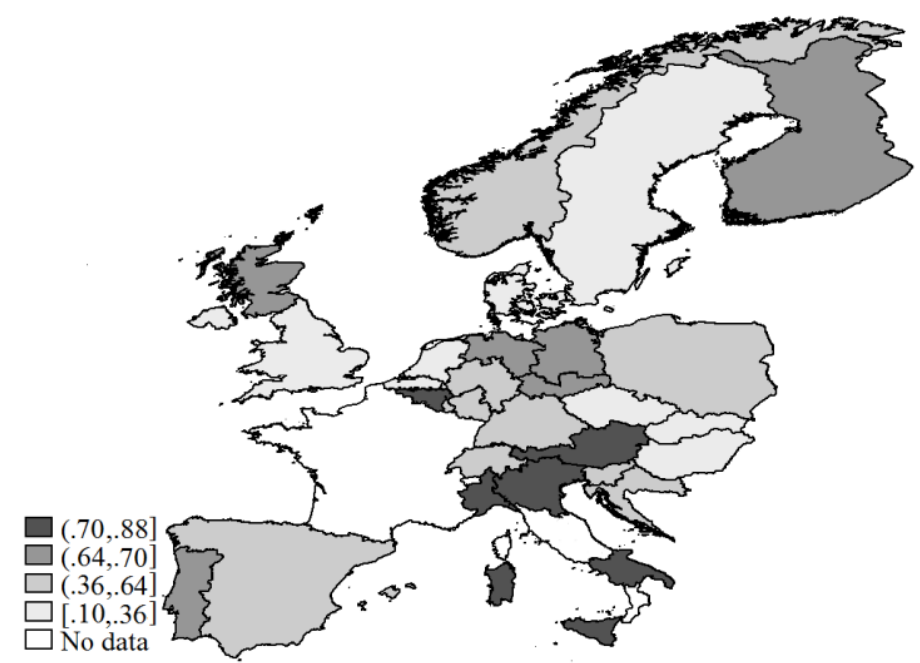

e. Content administration

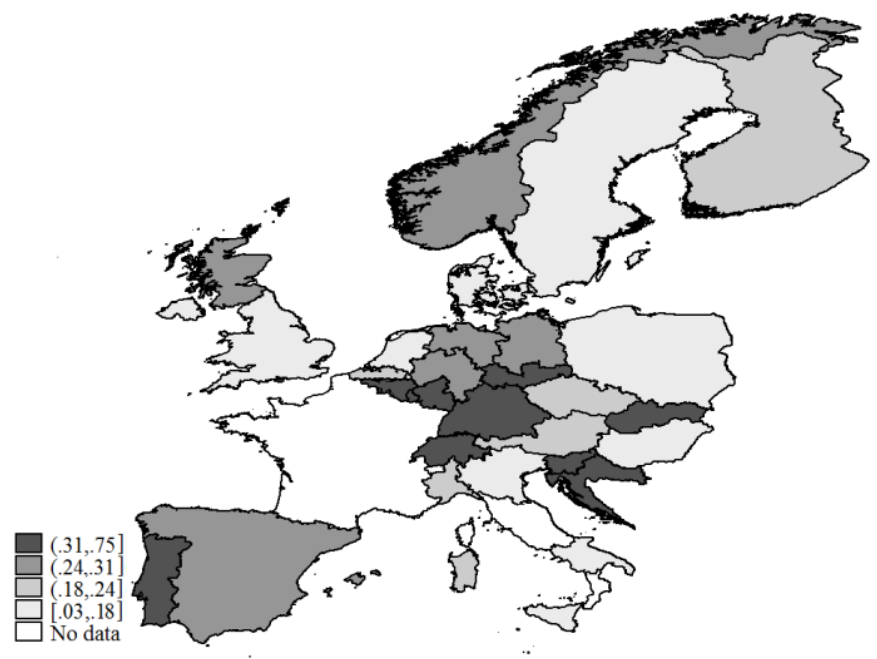


Notes: The borders are drawn at the lowest possible level at which the data are available. In the case of the number of tracks, the age of first selection and the central exit exams this means at the country level, or at the region level for French Belgium and Flemish Belgium and for England and Scotland, or at the state level for Germany. The borders for standardization deviate from this, in the sense that the lowest possible level for Germany is the state cluster level. See also Notes of Figure 1. 
Figure 3: Empires in Europe around 1800s

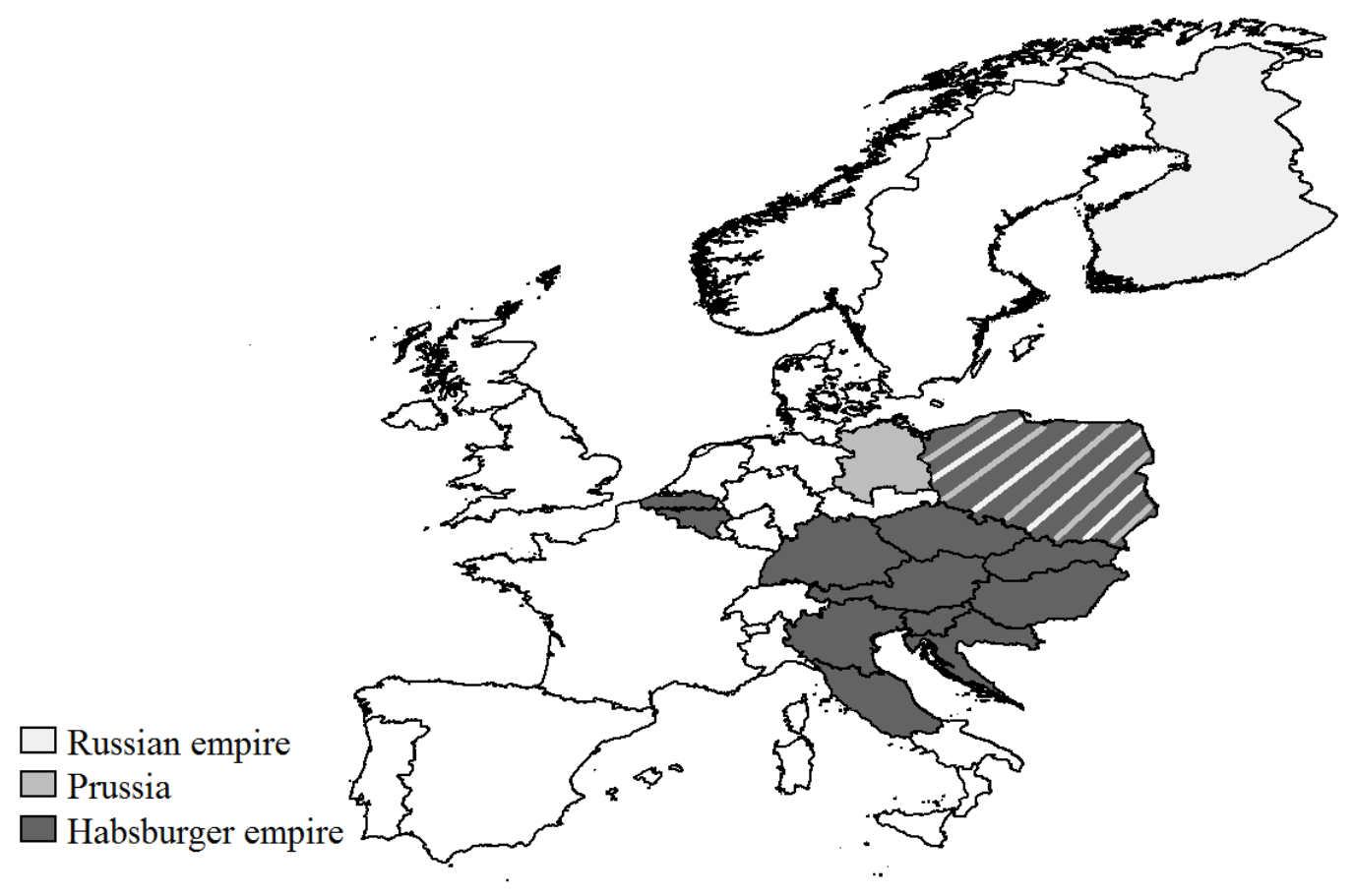

Notes: These maps are based on the Centennia Historical Atlas. Regions of Poland belonged to either Prussia (the North West), the Habsburger Empire (the south), and the Russian Empire (the east). See also Note 2 of Figure 1. 
TABLES

Table 1: Descriptive statistics education systems in Europe

\begin{tabular}{|l|lllll|}
\hline & Obs. & Mean & Std. Dev. & Min & Max \\
\hline Number of tracks & 29 & 2.83 & 1.28 & 1.00 & 5.00 \\
Age of first selection & 29 & 13.07 & 2.28 & 10.00 & 16.00 \\
Central Exit Exams & 26 & 0.42 & 0.48 & 0.00 & 1.00 \\
Administrative stand. & 29 & 0.52 & 0.23 & 0.10 & 0.88 \\
Content related stand. & 29 & 0.28 & 0.16 & 0.03 & 0.75 \\
Distance in km & 29 & 940.69 & 505.55 & 264.00 & 2304.00 \\
Empire & 29 & 0.45 & 0.51 & 0.00 & 1.00 \\
Pays réunis & 29 & 0.38 & 0.49 & 0.00 & 1.00 \\
Pays conquis & 29 & 0.24 & 0.44 & 0.00 & 1.00 \\
Pays allies & 29 & 0.21 & 0.41 & 0.00 & 1.00 \\
\hline \multicolumn{7}{|l}{ Notes. The sources of the variables are described in the text. } \\
\hline
\end{tabular}


Table 2: Pairwise correlations of the used variables

\begin{tabular}{|c|c|c|c|c|c|c|c|c|c|}
\hline & 1 & 2 & 3 & 4 & 5 & 6 & 7 & 8 & 9 \\
\hline 1. Number of tracks & 1.00 & & & & & & & & \\
\hline 2. Age of selection & -0.59 & 1.00 & & & & & & & \\
\hline 3. CEE & -0.25 & 0.19 & 1.00 & & & & & & \\
\hline 4. Admin. stand. & -0.02 & -0.01 & 0.33 & 1.00 & & & & & \\
\hline 5. Content stand. & 0.33 & -0.21 & -0.18 & 0.18 & 1.00 & & & & \\
\hline 6. Distance & -0.59 & 0.46 & 0.05 & -0.06 & -0.26 & 1.00 & & & \\
\hline 7. Pays réunis & 0.44 & -0.06 & -0.07 & 0.04 & 0.44 & -0.50 & 1.00 & & \\
\hline 8. Pays conquis & -0.05 & 0.09 & 0.28 & 0.11 & -0.23 & -0.14 & -0.11 & 1.00 & \\
\hline 9. Pays allies & -0.40 & 0.02 & 0.19 & 0.04 & 0.01 & 0.51 & -0.40 & -0.29 & 1.00 \\
\hline 10. Empire & 0.34 & -0.12 & -0.19 & 0.01 & 0.02 & 0.05 & -0.13 & -0.18 & 0.05 \\
\hline
\end{tabular}


Table 3: The effect of political pressure from Napoleon on the number of tracks

\begin{tabular}{|c|c|c|c|c|}
\hline & (1) & (2) & (3) & (4) \\
\hline Distance & $\begin{array}{l}-0.002 * * * \\
(0.000)\end{array}$ & $\begin{array}{l}-0.002 * * * \\
(0.000)\end{array}$ & $\begin{array}{l}-0.001 * * \\
(0.001)\end{array}$ & $\begin{array}{l}-0.001 * * \\
(0.000)\end{array}$ \\
\hline Empire & & $\begin{array}{l}1.031 * * \\
(0.375)\end{array}$ & & $\begin{array}{l}1.094 * * * \\
(0.387)\end{array}$ \\
\hline Pays réunis & & & $\begin{array}{l}0.486 \\
(0.532)\end{array}$ & $\begin{array}{l}0.726 \\
(0.476)\end{array}$ \\
\hline Pays conquis & & & $\begin{array}{l}-0.397 \\
(0.537)\end{array}$ & $\begin{array}{l}-0.097 \\
(0.484)\end{array}$ \\
\hline Pays allies & & & $\begin{array}{l}-0.151 \\
(0.649)\end{array}$ & $\begin{array}{l}-0.051 \\
(0.573)\end{array}$ \\
\hline Constant & $\begin{array}{l}4.344 * * * \\
(0.444)\end{array}$ & $\begin{array}{l}3.932 * * * \\
(0.426)\end{array}$ & $\begin{array}{l}4.053 * * * \\
(0.677)\end{array}$ & $\begin{array}{l}3.326 * * * \\
(0.649)\end{array}$ \\
\hline Observations & 29 & 29 & 29 & 29 \\
\hline Adjusted $\mathrm{R}^{2}$ & 0.32 & 0.45 & 0.29 & 0.45 \\
\hline $\mathrm{p} F$ test & 0.001 & 0.000 & 0.014 & 0.002 \\
\hline
\end{tabular}


Table 4: The effect of political pressure from Napoleon on the age of first selection

\begin{tabular}{|c|c|c|c|c|}
\hline & (1) & (2) & (3) & (4) \\
\hline Distance & $\begin{array}{l}0.002 * * \\
(0.001)\end{array}$ & $\begin{array}{l}0.002 * * \\
(0.001)\end{array}$ & $\begin{array}{l}0.003 * * * \\
(0.001)\end{array}$ & $\begin{array}{l}0.003 * * * \\
(0.001)\end{array}$ \\
\hline Empire & & $\begin{array}{l}-0.919 \\
(0.807)\end{array}$ & & $\begin{array}{l}-0.760 \\
(0.828)\end{array}$ \\
\hline Pays réunis & & & $\begin{array}{l}0.788 \\
(0.998)\end{array}$ & $\begin{array}{l}0.621 \\
(1.018)\end{array}$ \\
\hline Pays conquis & & & $\begin{array}{l}0.574 \\
(1.007)\end{array}$ & $\begin{array}{l}0.365 \\
(1.035)\end{array}$ \\
\hline Pays allies & & & $\begin{array}{l}-1.643 \\
(1.218)\end{array}$ & $\begin{array}{l}-1.712 \\
(1.224)\end{array}$ \\
\hline Constant & $\begin{array}{l}11.140^{* * *} \\
(0.863)\end{array}$ & $\begin{array}{l}11.510 * * * \\
(0.917)\end{array}$ & $\begin{array}{l}9.982 * * * \\
(1.270)\end{array}$ & $\begin{array}{l}10.490 * * * \\
(1.387)\end{array}$ \\
\hline Observations & 29 & 29 & 29 & 29 \\
\hline Adjusted $\mathrm{R}^{2}$ & 0.17 & 0.18 & 0.20 & 0.19 \\
\hline $\mathrm{p} F$ test & 0.015 & 0.028 & 0.053 & 0.074 \\
\hline
\end{tabular}


Table 5: The effect of political pressure from Napoleon on the existence of central examinations

\begin{tabular}{|c|c|c|c|c|}
\hline & (1) & (2) & (3) & (4) \\
\hline \multirow[t]{2}{*}{ Distance } & 0.000 & 0.000 & -0.000 & -0.000 \\
\hline & $(0.000)$ & $(0.000)$ & $(0.000)$ & $(0.000)$ \\
\hline \multirow[t]{2}{*}{ Empire } & & -0.170 & & -0.180 \\
\hline & & $(0.207)$ & & $(0.215)$ \\
\hline \multirow[t]{2}{*}{ Pays réunis } & & & 0.031 & -0.039 \\
\hline & & & $(0.269)$ & $(0.284)$ \\
\hline \multirow[t]{2}{*}{ Pays conquis } & & & 0.401 & 0.364 \\
\hline & & & $(0.262)$ & $(0.268)$ \\
\hline \multirow[t]{2}{*}{ Pays allies } & & & 0.463 & 0.463 \\
\hline & & & $(0.297)$ & $(0.299)$ \\
\hline \multirow[t]{2}{*}{ Constant } & $0.414 *$ & $0.484 * *$ & 0.350 & 0.489 \\
\hline & $(0.214)$ & $(0.232)$ & $(0.310)$ & $(0.354)$ \\
\hline Observations & 26 & 26 & 26 & 26 \\
\hline Adjusted $\mathrm{R}^{2}$ & -0.04 & -0.05 & 0.00 & -0.02 \\
\hline $\mathrm{p} F$ test & 0.802 & 0.695 & 0.445 & 0.498 \\
\hline
\end{tabular}


Table 6: The effect of political pressure from Napoleon on the administrative standardization

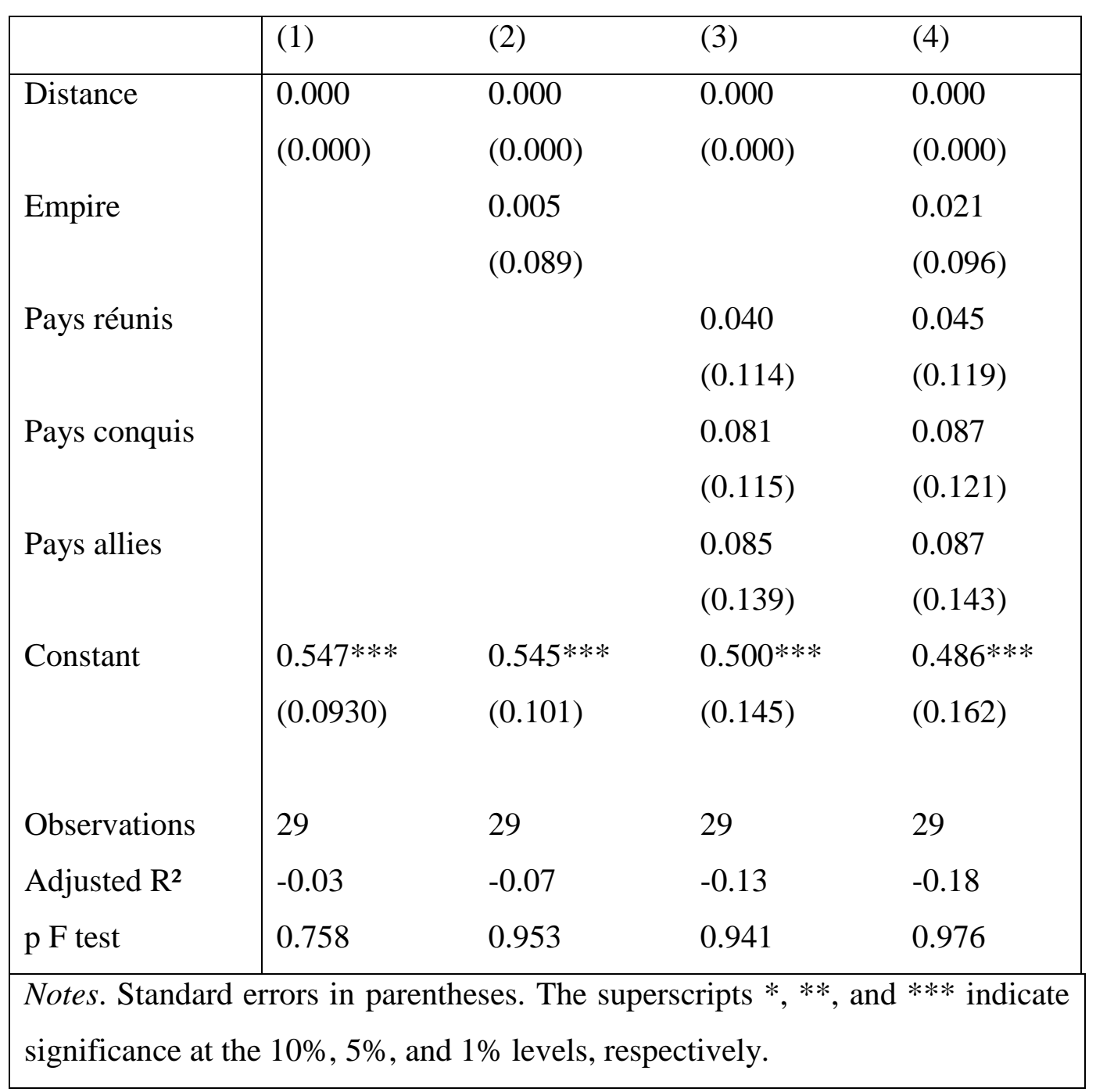


Table 7: The effect of political pressure from Napoleon on the content related standardization

\begin{tabular}{|c|c|c|c|c|}
\hline & (1) & (2) & (3) & (4) \\
\hline Distance & $\begin{array}{l}0.000 \\
(0.000)\end{array}$ & $\begin{array}{l}0.000 \\
(0.000)\end{array}$ & $\begin{array}{l}0.000 \\
(0.000)\end{array}$ & $\begin{array}{l}0.000 \\
(0.000)\end{array}$ \\
\hline Empire & & $\begin{array}{l}0.011 \\
(0.060)\end{array}$ & & $\begin{array}{l}0.016 \\
(0.058)\end{array}$ \\
\hline Pays réunis & & & $\begin{array}{l}0.140 * \\
(0.069)\end{array}$ & $\begin{array}{l}0.144 * \\
(0.072)\end{array}$ \\
\hline Pays conquis & & & $\begin{array}{l}-0.052 \\
(0.070)\end{array}$ & $\begin{array}{l}-0.048 \\
(0.073)\end{array}$ \\
\hline Pays allies & & & $\begin{array}{l}0.095 \\
(0.084)\end{array}$ & $\begin{array}{l}0.097 \\
(0.086)\end{array}$ \\
\hline Constant & $\begin{array}{l}0.357 * * * \\
(0.063)\end{array}$ & $\begin{array}{l}0.353 * * * \\
(0.069)\end{array}$ & $\begin{array}{l}0.276^{* * *} \\
(0.088)\end{array}$ & $\begin{array}{l}0.266^{* *} \\
(0.098)\end{array}$ \\
\hline Observations & 29 & 29 & 29 & 29 \\
\hline Adjusted $\mathrm{R}^{2}$ & 0.04 & 0.00 & 0.16 & 0.13 \\
\hline $\mathrm{p} F$ test & 0.166 & 0.384 & 0.0865 & 0.153 \\
\hline
\end{tabular}

